\title{
10 National and Local Contingency Planning: a Com- parative Analysis of Plans in Africa and Latin America
}

\begin{abstract}
The past twenty years have provided evidence that preventive preparation of exposed communities can reduce the impact of natural disasters, hence the creation of contingency plans. Today these plans are adopted at various scales, precisely national, regional, municipal and, at times, even village-centred. But the consistency of contingency plans and their interconnection with the various scales is rarely achieved, especially in Least Developed Countries. The contingency device should not only be organised at various territorial levels, but it should also enable the actors to take coordinated action in case of a disaster. This crucial point is still scarcely discussed in the literature. The scope of this chapter is to present the differences between national and local contingency planning, the relationship between the two scales and the weak points that can still be found in the procedure. Eight contingency plans are compared, namely 5 national (Guinea, Haiti, Madagascar, Mozambique, Senegal) and 3 local (Ecuador, Haiti, Peru). The analysis diagram proposed by Choularton (2007) has been used as a reference for the presentation of the various planning scales, phases, scenarios and considerations on climate change.
\end{abstract}

Keywords: Contingency plans, Scenarios, Least Developed Countries

\subsection{Introduction}

In case of a natural disaster, the intervention of humanitarian organisations can make the difference between life and death for thousands of people. These organisations have made considerable progress in preparing interventions through contingency plans that involve "making decisions in advance about the management of human and financial resources, coordination and communications procedures, and being aware of a range of technical and logistic responses” (IFRC 2015). Contingency planning analyses the potential impact of a disaster, anticipates problems that might occur during the humanitarian intervention, and organises the response in advance (CARE 2006) in order to promptly respond to the needs of the population affected by the disaster. Planning the response to the emergency entails discussing the issues and limited resources available with personnel.

25 Enrico Ponte, urban planner PhD, holds a research grant at the DIST-Politecnico and Università di Torino enrico.ponte@polito.it

The author would like to thank Maurizio Tiepolo (DIST-Politecnico and Università di Torino) for his suggestions while writing the chapter. 
Experience indicates that a prompt response to a crisis reduces its impact. This depends on the expertise and plans of organisations that first intervene in affected areas (Swart et al. 2009).

However, the majority of contingency plans put more emphasis on the plan's formulation and on defining actions than on testing, evaluating and refining the plan (UNISDR 2012). Hence, contingency plan assessments that can help us strengthen the contingency device are still very few (IFRC 2012).

The aim of this chapter is to define the main features of contingency plans at the various territorial scales, and the critical aspects that hinder their effective implementation in case of a disaster.

This chapter presents phases, actors and scenarios of eight contingency plans, primarily designed for Least Developed Countries (LDC), namely 5 national (Guinea, Haiti, Madagascar, Mozambique, Senegal) and 3 local (Urdaneta, Ecuador; Tabarre, Haiti, Lima, Peru).

\subsection{Contingency Plans}

Contingency planning, which is at times defined as emergency planning, specifies how a single organisation, a whole community (from region to village) or a country must behave in case of drought, earthquake, flood, heatwave, landslide or mud flow (WFP 2010). Hence, contingency planning identifies potential disasters and establishes how to manage them (James 2008). This entails simulating the procedures to be followed in frameworks that can become problematic in order to be ready when required.

When an emergency occurs, contingency planning optimises the response (IFRC 2012), which must be rapid, appropriate and efficient (WFP 2010). A contingency plan establishes the management of human and financial resources, as well as the coordination and communication procedures in advance. The plan is a management tool for all sectors that can rapidly and effectively provide humanitarian aid to those who need it in case of a disaster (Ackermann 2013). The time spent on contingency planning is time that will be saved in case of a disaster.

Contingency planning is an ongoing process (Choularton 2007). The plans must be tested and updated to ascertain their relevance, especially in rapidly evolving frameworks (great migratory flows, devastating natural disasters). Contingency planning, the importance of which is readily acknowledged today (Mitchell 2008), must always be performed when there is a high risk of either a disaster or an emergency. In this case, the periods in which natural catastrophes are recurrent (e.g. seasonal event, such as floods, hurricanes or cyclones and drought) must also be defined.

Very often contingency planning is an informal process because it is carried out by individuals or groups of individuals who have not been assigned to do it by any authority. However, formal contingency planning too features a considerable degree 
of informality, which is deemed useful, though it follows a commonly agreed and defined process that is converted into an emergency plan (IASC 2007, Choularton 2007). Contingency plans should start by identifying the areas exposed to disaster by the communities concerned (Pasteur 2011).

Climate change increases the hazards to which a community is exposed and, at times, introduces new ones. Contingency planning should carefully consider the changes in progress and forecasts of their future progress when preparation for, response to and recovery from a disaster are defined (Vogel et al. 2012).

\subsubsection{The Implementation Scale of Plans}

Most contingency plans are organised on a national scale in order to ensure coordination and response to very big disasters. At times potential disasters are so vast (hurricanes, cyclones) that contingency plans even involve several countries.

Local governments play a role of primary importance in national plans because, according to the principle of subsidiarity, the administration that is closest to the population with limited access to community services will be required to reduce the gap (UNDP 2010a) (Figure 10.1). Basically, if a local government can efficiently provide a specific service, it should be assigned this responsibility (Wilson 2006). National and local governments can significantly reduce the risk generated by climate change, for instance, with a precisely planned response to disasters (rescue services, emergency services and medical assistance) and reconstruction (assistance to those who have lost their home and means of survival) designed to enhance resilience (Satterthwaite et al. 2007).

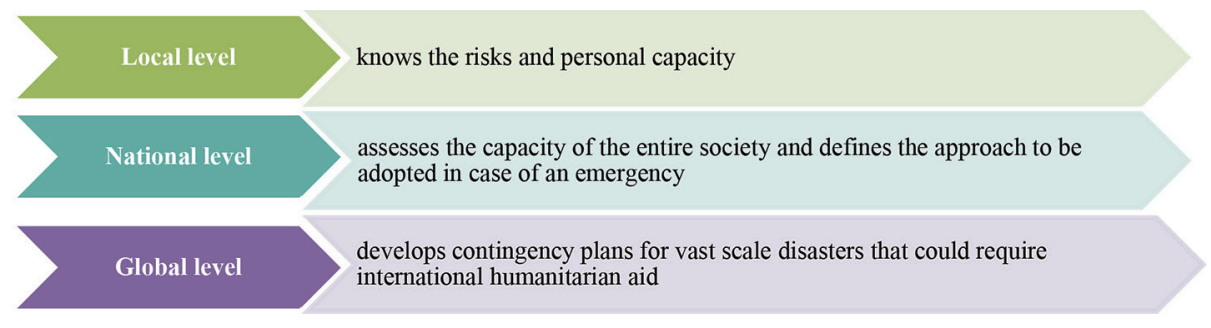

Figure 10.1: The three territorial levels of contingency plans (IFRC 2012)

\subsubsection{Phases of Contingency Planning}

Though the major part of humanitarian organisations follow their own guidelines for drawing up contingency plans, they present certain common phases, such as description of scenarios, strategic response, preparation for the plan, implementation of the plan, operations to support the plan, and budgeting (Table 10.1). Local 
contingency plans should be consistent with provincial or regional contingency plans (IASC 2007b). For instance, the databases and maps created by regional plans will be useful to locate temporary recovery facilities and evacuation routes on a local scale (UNDP 2008).

Table 10.1: Principal phases of contingency planning (Choularton 2007)

\begin{tabular}{|c|c|c|}
\hline Phase & Usefulness & Notes \\
\hline Scenario & $\begin{array}{l}\text { Provide the foundations for } \\
\text { planning } \\
\text { Generate consent on the nature } \\
\text { of the potential crisis }\end{array}$ & $\begin{array}{l}\text { Simple and general, if there is no specific } \\
\text { threat Detailed in case of an emerging crisis }\end{array}$ \\
\hline $\begin{array}{l}\text { Strategic } \\
\text { response }\end{array}$ & $\begin{array}{l}\text { Define the humanitarian } \\
\text { responses }\end{array}$ & $\begin{array}{l}\text { Strategy for a simple response, if there is no } \\
\text { threat, complex in case of an emerging crisis }\end{array}$ \\
\hline $\begin{array}{l}\text { Implementation } \\
\text { of the plan }\end{array}$ & Implement the response & Detailed planning in case of a potential crisis \\
\hline $\begin{array}{l}\text { Support for the } \\
\text { plan }\end{array}$ & $\begin{array}{l}\text { Identify human, administrative, } \\
\text { financial and safety resources }\end{array}$ & $\begin{array}{l}\text { Support is more effective in case of a potential } \\
\text { crisis }\end{array}$ \\
\hline $\begin{array}{l}\text { Preparation for } \\
\text { the plan }\end{array}$ & $\begin{array}{l}\text { Identify the actions that can be } \\
\text { carried out before a crisis }\end{array}$ & $\begin{array}{l}\text { Preparation is useful when there is no specific } \\
\text { threat }\end{array}$ \\
\hline Budget & $\begin{array}{l}\text { Define the cost of preparing an } \\
\text { emergency response }\end{array}$ & $\begin{array}{l}\text { The budget is more useful in case of an emer- } \\
\text { ging crisis, and can be converted into a project } \\
\text { budget } \\
\text { The budget for preparation activities is recom- } \\
\text { mended in all phases of the process }\end{array}$ \\
\hline
\end{tabular}

\subsubsection{Defining the Scenarios}

All contingency plans are based on the definition of scenarios, namely an assumption of what might occur following a potential natural disaster (IFRC 2012). A very accurate scenario will improve the organisation of the response (UNCHR 2011). Today, there are several methods for defining possible scenarios (Sikisch 1995). Usually three scenarios are developed, precisely the best, the worst and an intermediate one (Choularton 2007) (Table 10.2).

Contingency plans that include scenarios of climate change, such as the ones defined by the IPCC, are still few and are, generally, flood emergency plans. Two examples include the plan for the Colorado River Basin that was affected in recent years by drought (USBR 2014), and Durban's contingency plan in the framework of the climate adaptation plan (Cartwright et al. 2013). 
Table 10.2: Potential damages for three scenarios in case of drought, floods and earthquake (Choularton 2007)

\begin{tabular}{llll}
\hline Scenario & Drought & Floods & Earthquake \\
\hline Best & Absent & Absent & 4.5 Richter's scale, minor damages \\
\hline Probable & $\begin{array}{l}\text { In one part of the } \\
\text { country }\end{array}$ & $\begin{array}{l}100,000 \text { disaster } \\
\text { victims }\end{array}$ & $\begin{array}{l}\text { 6.5 Richter's scale, damages to rural } \\
\text { areas and small cities }\end{array}$ \\
\hline Worst & $\begin{array}{l}\text { In the major part } \\
\text { of the country }\end{array}$ & $\begin{array}{l}1,000,000 \text { disaster } \\
\text { victims }\end{array}$ & $\begin{array}{l}\text { 8.0 Richter's scale, epicentre in a } \\
\text { metropolis }\end{array}$ \\
\hline
\end{tabular}

The scenario-based approach allows planners to work on various scales for the same potential crisis. For instance, the definition of the National Contingency Plan can resort to information provided by people from various regions. The construction of scenarios also exploits the "step by step" approach to describe the potential escalation of a crisis and of the corresponding measures required. This approach is often adopted to manage refugee flows. When the degree of aggravation of the crisis increases the number of refugees, thresholds are defined beyond which additional measures or more economic resources are demanded. For instance, every scenario of UNHCR contingency plans envisages additional measures (Table 10.3); hence, such a scenario is defined as "step by step."

Table 10.3: Measures for four scenarios based on the number of refugees (Choularton 2007)

\begin{tabular}{lll}
\hline Scenario & Refugees no. & Measures \\
\hline 1 & 5,000 & $\begin{array}{l}\text { Record and protect the refugees who } \\
\text { stay with hosting families }\end{array}$ \\
\hline 2 & 15,000 & $\begin{array}{l}\text { Open a refugee camp } \\
\text { Appoint an Emergency Manager } \\
\text { Buy a pickup truck to distribute aid }\end{array}$ \\
\hline 3 & 50,000 & $\begin{array}{l}\text { Open a second refugee camp } \\
\text { Increase personnel by } 5 \text { units } \\
\text { Rent a warehouse }\end{array}$ \\
\hline 4 & 100,000 & $\begin{array}{l}\text { Open a third refugee camp } \\
\text { Increase personnel by } 6 \text { units } \\
\text { Expand the warehouse }\end{array}$ \\
\hline
\end{tabular}




\subsection{Examples of Contingency Plans}

By analysing eight plans we can better understand how they are organised. The plans considered are five national (Guinea, Mozambique, Senegal, Madagascar and Haiti), and three urban (Lima, Peru; Tabarre, Haiti; Urdaneta, Ecuador).

\subsubsection{National Contingency Plans}

The five plans analysed were drawn up between 2009 (Senegal) and 2013 (Haiti) (Table 4). With regard to the scenarios considered, Haiti's plan (MPCE 2013) and Senegal's plan (UNDP 2009) define scenarios based on the number of hours or days that have elapsed after the event. For every scenario, the plan specifies the activities to be carried out, the people to be mobilised, and the areas to be monitored.

Table 10.4: Comparison of 5 national contingency plans.

\begin{tabular}{|c|c|c|c|c|c|}
\hline $\begin{array}{l}\text { Phase of } \\
\text { the plan }\end{array}$ & $\begin{array}{l}\text { Guinea } \\
\text { (UNDP 2012) }\end{array}$ & $\begin{array}{l}\text { Haiti } \\
\text { (MPCE 2013) }\end{array}$ & $\begin{array}{l}\text { Madagascar } \\
\text { (BNGRC 2011) }\end{array}$ & $\begin{array}{l}\text { Mozambique } \\
\text { (UNDP 2010b) }\end{array}$ & $\begin{array}{l}\text { Senegal } \\
\text { (UNDP 2009) }\end{array}$ \\
\hline Scenario & $\begin{array}{l}\text { Best, proba- } \\
\text { ble, worst }\end{array}$ & $\begin{array}{l}\text { Temporal } \\
\text { (Day 1, Day 2, ...) }\end{array}$ & $\begin{array}{l}2 \text { scenarios } \\
\text { based on the } \\
\text { cyclone season }\end{array}$ & $\begin{array}{l}3 \text { scenarios } \\
\text { based on the } \\
\text { probability of } \\
\text { occurrence }\end{array}$ & $\begin{array}{l}\text { Temporal } \\
(24 \mathrm{~h}, 48 \mathrm{~h}, \ldots)\end{array}$ \\
\hline $\begin{array}{l}\text { Strategic } \\
\text { response }\end{array}$ & $\begin{array}{l}\text { For every } \\
\text { administrative } \\
\text { unit (cluster) }\end{array}$ & None & $\begin{array}{l}\text { Entrusted to } \\
\text { the individual } \\
\text { clusters }\end{array}$ & $\begin{array}{l}\text { Strategies for } \\
\text { each cluster }\end{array}$ & Based on the risk \\
\hline $\begin{array}{l}\text { Implementa- } \\
\text { tion }\end{array}$ & $\begin{array}{l}\text { - Detailed time- } \\
\text { line of the } \\
\text { programme }\end{array}$ & $\begin{array}{l}\text { Estimated } \\
\text { community needs } \\
\text { and response } \\
\text { capacity }\end{array}$ & $\begin{array}{l}\text { Presentation of } \\
\text { s clusters and logi- } \\
\text { stic, administra- } \\
\text { tive responses }\end{array}$ & $\begin{array}{l}\text { Presentation of } \\
\text { - clusters, logistic } \\
\text { and administra- } \\
\text { tive responses }\end{array}$ & $\begin{array}{l}\text { Logistic and } \\
\text { administrative } \\
\text { responses }\end{array}$ \\
\hline Support & $\begin{array}{l}\text { Humanitarian } \\
\text { Coordinator }\end{array}$ & $\begin{array}{l}\text { Identification of } \\
\text { available local } \\
\text { human resources }\end{array}$ & $\begin{array}{l}\text { National Council } \\
\text { for Risk and } \\
\text { Disaster Manage- } \\
\text { ment }\end{array}$ & $\begin{array}{l}\text { The UN Coordi- } \\
\text { nator appoints } \\
\text { - the Humanitarian } \\
\text { Coordinator }\end{array}$ & $\begin{array}{l}\text { Appointment of } \\
\text { a Humanitarian } \\
\text { Coordinator, } \\
\text { other human } \\
\text { resources }\end{array}$ \\
\hline $\begin{array}{l}\text { Preparation } \\
\text { for the plan }\end{array}$ & $\begin{array}{l}\text { Actions to be } \\
\text { implemen- } \\
\text { ted for each } \\
\text { cluster }\end{array}$ & $\begin{array}{l}\text { Role of national, } \\
\text { departmental } \\
\text { and municipal } \\
\text { operative centres }\end{array}$ & $\begin{array}{l}\text { Actions to be } \\
\text { implemented for } \\
\text { each cluster in } \\
24 \mathrm{~h}, 48 \mathrm{~h} \text {, etc. }\end{array}$ & $\begin{array}{l}\text { Actions to be } \\
\text { implemented, } \\
\text { appointment of } \\
\text { Cluster Managers }\end{array}$ & $\begin{array}{l}\text { Actions to be } \\
\text { implemented for } \\
\text { each cluster }\end{array}$ \\
\hline Budget & Absent & Detailed & $\begin{array}{l}\text { Detailed based } \\
\text { on needs and } \\
\text { scenarios }\end{array}$ & Absent & Absent \\
\hline
\end{tabular}


The plans for Guinea (UNDP 2012) and Mozambique (UNDP 2010b) define three scenarios (better, probable and worst), indicating the procedures to be followed for each of them. Madagascar's plan refers to the different periods of the year, based on the cyclone season.

The strategic response refers almost entirely to clusters, which are either precisely described (Madagascar) or barely outlined (Haiti).

The plans are specifically implemented by administrative and political actors according to the various logistic duties defined in the scenarios. In the case of Haiti, the plan requires an assessment of the needs and response capacity of the various population groups when a disaster occurs.

Some plans define specific figures, such as the Humanitarian Coordinator or the Emergency Manager (Guinea, Madagascar, Mozambique), while others recall the need to mobilise a larger number of people for emergency management (Haiti and Senegal).

As regards drawing up plans, the various clusters are assigned precise roles based on the number of hours or days that have elapsed after the event (Madagascar), or on the scenario (Senegal).

In 3 out of 5 cases, the budget is not specified (Guinea, Mozambique, Senegal), while it is detailed by items for Madagascar.

\subsubsection{Local Contingency Plans}

The three plans analysed were drawn up in 2011 (Lima and Urdaneta) and in 2014 (Tabarre). These administrative authorities are quite different in terms of dimensions and population, so they are representative of the various types of local plans. Lima has a surface area of $2,672 \mathrm{~km}^{2}$ and counts 7.6 million inhabitants. Urdaneta has a surface area of $290 \mathrm{~km}^{2}$ and has 29,000 inhabitants (2010). Tabarre is a municipality in Port-au-Prince, about $10 \mathrm{~km}$ from the centre of the capital city, which stretches over $25 \mathrm{~km}^{2}$ and counts 170,000 inhabitants. It has an international airport, the American embassy and several UN operation sites. Tabarre's contingency plan can be considered an integration to the national one, considering the low quality of the departmental contingency plan. It follows the provisions laid down by the National Contingency Plan and the local scale structure to provide useful and simple tools for the local authorities (Table 10.5).

Compared to national plans, the ones for Lima and Tabarre define the scenarios (weak, moderate and catastrophic), and the objective, response and preparation for each of them (Table 10.6). Urdaneta's plan, instead, describes geographical scenarios that refer to precise territorial sectors. Climate change is not one of the scenarios considered.

Responses either implement national plans and strategies (Lima, Urdaneta), or they are carried out locally (Tabarre). In the case of local plans, the resources avail- 
Table 10.5: Summary of the analysis of three local contingency plans.

\begin{tabular}{llll}
\hline Plan phase & $\begin{array}{l}\text { Lima } \\
\text { (COOPI 2011) }\end{array}$ & $\begin{array}{l}\text { Tabarre } \\
\text { (COOPI 2014) }\end{array}$ & $\begin{array}{l}\text { Urdaneta } \\
\text { (Los Rios Prefectura } \\
\text { 2011) }\end{array}$ \\
\hline Scenario & $\begin{array}{l}\text { According sectors } \\
\text { of the city }\end{array}$ & $\begin{array}{l}\text { Light, moderate, } \\
\text { catastrophic }\end{array}$ & High, medium, low \\
\hline $\begin{array}{l}\text { Strategic } \\
\text { response }\end{array}$ & $\begin{array}{l}\text { Refer to the Strategic } \\
\text { development plan }\end{array}$ & $\begin{array}{l}\text { According sectors and } \\
\text { scenarios }\end{array}$ & Not specified \\
\hline Implementation & $\begin{array}{l}\text { Commissions for protocols } \\
\text { planning and coordination }\end{array}$ & $\begin{array}{l}\text { Identification of strength } \\
\text { and weakness of institutions } \\
\text { and organisations }\end{array}$ & $\begin{array}{l}\text { Operative procedures } \\
\text { by sector }\end{array}$ \\
\hline $\begin{array}{l}\text { Support } \\
\text { operations }\end{array}$ & Emergency communication, & Civil protection, local \\
coordination and control & authorities, United Nations & Responsibility assigned \\
Preparation & Specified & Specified by sectors & Specified by sectors \\
\hline Budget & Absent & Absent & Absent \\
\hline
\end{tabular}

Table 10.6: Tabarre (Haiti). Objectives, response and preparation according to scenario 3.

\begin{tabular}{|c|c|c|c|}
\hline Scenario 3 & Objectives & Response & Preparation \\
\hline $\begin{array}{l}\text { Disaster } \\
\text { victims }\end{array}$ & $\begin{array}{l}\text { Evacuate, provide accommodation } \\
\text { and food to disaster victims within } \\
72 \text { hours } \\
\text { Psychological assistance } \\
\text { Economic aid for funerals }\end{array}$ & $\begin{array}{l}\text { Hospitality sites } \\
\text { Distribution of water, } \\
\text { food, hygiene kits } \\
\text { from the second week }\end{array}$ & $\begin{array}{l}\text { Chemical toilets (mobile) } \\
\text { Food stocks } \\
\text { Agreements with dispen- } \\
\text { saries and NGOs }\end{array}$ \\
\hline Community & $\begin{array}{l}\text { Create access routes } \\
\text { Repair damaged streets } \\
\text { Drinking water }\end{array}$ & $\begin{array}{l}\text { Human resources of } \\
\text { the municipality }\end{array}$ & $\begin{array}{l}\text { List of materials available } \\
\text { Establish watering points }\end{array}$ \\
\hline
\end{tabular}

able are often limited. Hence, achieving the objectives inevitably depends on actors and competences situated outside the municipality. However, the coordinated action of the municipal Civil Defence Department, municipality, NGOs, committees and local organisations can reduce the impact of the disaster. Constantly updated needs assessment and a training plan can contribute to achieve the goals of the plan.

Regarding the implementation of the plan, dedicated committees that establish communications between actors involved in formal and informal planning procedures are created in Lima. Moreover, coordination protocols are defined to be implemented during emergency response phases. Instead, the actors to be involved in case of a natural disaster (national and departmental civil defence, the United Nations, the 
Red Cross, etc.) are specified in Tabarre, taking into account the precarious political and administrative situation. Urdaneta's plan (Los Rios Prefectura 2011) provides a detailed description of the roles played by both public administration and society.

None of the three plans has a budget. In the case of Tabarre, preparation costs are included in the annual budget of the Civil Defence Department, while emergency funds are allocated for the specific situation.

Tabarre's plan has a map. It would be helpful if maps were always present as a useful tool for people who will have to implement the plan.

All the plans analysed neglected disaster simulations that would train the actors.

The national and local plans are complementary. However, a local plan can mirror the national one, but the reverse is never the case.
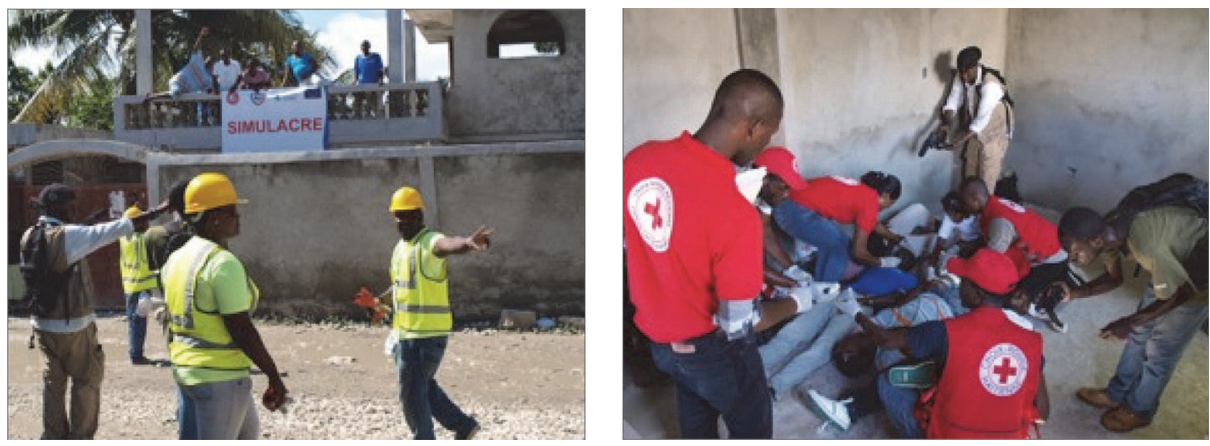

Figure 10.2: Tabarre (Haiti), 2013. Simulations envisaged by the emergency plan (photo E. Ponte)

\subsection{Conclusions}

The comparative analysis of 8 contingency plans, especially for LDC, underscored some weak points.

First, national contingency plans that are not associated with departmental and local contingency plans, have a low impact potential. This is often the case of LDCs.

Second, the coordination between local, national and international actors breaks down without a local contingency plan, and so does the prompt efficiency of the response (Choularton 2007).

Third, the lack of an Emergency Manager reduces the efficacy of the response.

Four, neglecting the climate change in progress and its envisaged future progress impairs the quality of contingency plans. This common deficiency is now being improved in the contingency plans of advanced economies.

Five, the lack of physical plans for territories exposed to hazards (Haiti) entails that urban expansion is not managed, natural resources are exploited in an unsustainable manner, and both factors hinder emergency management. 
Six, without strengthening the municipal administration with regard to disaster management and without economic aid provided by the national government (Haiti), local governments are unable to independently draw up their own contingency plans.

Though the plans considered present several specificities, the above deficiencies are common in many other Least Developed Countries.

\section{References}

Ackermann, M. 2013. Mine closure: a contingency plan to mitigate socio-economic disasters. Magister degree in Development and management at the Potchefstroom Campus of the North-West University.

BNGRC-Bureau National de Gestion des Risques et des Catastrophes du Madagascar. 2011. Plan national de contingence sur les cyclones et les inondations.

CARE. 2006. Emergency preparedness planning guidelines. London.

Cartwright, A., J. Blignaut, M.D. Wit, K. Goldberg et al. 2013. Economics of climate change adaptation at the local scale under conditions of uncertainty and 2010-11 constraints: the case of Durban, South Africa. Environment and Urbanization 25(1): 1-18.

Choularton, R. 2007. Contingency planning and humanitarian action: a review of practice, HPN Network Paper 59.

COOPI-Cooperazione Internazionale. 2011. Plan de operaciones de emergencia ante sismos centro histórico de Lima. Lima.

COOPI. 2014. Plan de contingence communal de Tabarre de 2014.

IASC-Inter-Agency Standing Committee. 2007a. Inter-agency contingency planning guidelines for humanitarian assistance. Geneva: IASC working group.

IASC. 2007b. Challenges and suggestions for enhancing inter-agency contingency planning: report of the 1st Global consultation of contingency planners in humanitarian agencies.

IFRC-International Federation of Red Cross and red crescent societies. 2015. Contingency planning. http://www.ifrc.org/en/what-we-do/disaster-management/preparing-for-disaster/disasterpreparedness-tools/contingency-planning-and-disaster-response-planning/. Accessed 6 Dec 2015.

IFRC. 2012. Contingency planning guide. Geneva: IFRC.

James, E. 2008. Managing humanitarian relief an operational guide for NGO's. Intermediate Technology Publications Ltd.

Los Rios Prefectura. 2011. Plan de contingencia por inundación Cantón Urdaneta, Urdaneta, Ecuador.

Mitchell, T., and M. van Aalst 2008. Convergence of disaster risk reduction and climate change adaptation. London: DFID.

Pasteur, K. 2011. From vulnerability to resilience. A framework for analysis and action to build community resilience. Rugby: Practical Action Publishing Ltd.

Satterthwaite, D., S. Huq, M. Pelling, H. Reid, and P. Romero Lankao. 2007. Adapting to climate change in urban areas. The possibilities and constraints in low- and middle-income nations. London: IIED.

Sikisch, G. 1995. Emergency management planning handbook. New York: McGraw-Hill.

Swart, R., R. Biesbroeck, S. Binnerup et al. 2009. Europe adapts to climate change: comparing national adaptation. Helsinki: SYKE-Finnish Environment Institute.

USBR-United States Bureau of Reclamation. 2014. Reclamation, managing water in the west. Climate change adaptation strategy.

UNDP-United Nations Development Program. 2012. Plan de contingence multirisque de la Guinée. 
UNDP. 2010a. Local governance and climate change. Discussion note.

UNDP. 2010b. Mozambique humanitarian country team inter-agency contingency plan. Maputo. UNDP. 2009. Plan de contingence pour la République du Sénégal. Dakar.

UNDP. 2008. Mainstreaming disaster risk reduction in sub national development and land use/ physical planning in the Philippines. National Economic and Development Authority.

UNHCR. 2011. Contingency planning. Learning module. Tokyo. http://www.coordinationtoolkit.org/ wp-content/uploads/UNHCR-Contingency-Planning-Training-Module.pdf. Accessed 5 Dec 2015. UNISDR. 2012. Drought contingency plans and planning in the Greater horn of Africa. Geneva. Vogel, J., E. Gordon, J. Brislawn et al. 2012. Boulder county climate change preparedness plan.

Boulder: Boulder county commissioner's sustainability office.

WFP-World Food Program. 2000. Contingency planning guidelines. Rome.

Wilson, E. 2006. Adapting to climate change at the local level: The spatial planning response. Local Environment. The International Journal of Justice and Sustainability 11(6): 609-625. 